\title{
Investigation on the Performance of a Portable Power Generation System with a Low-Cost Vertical Axis Wind Turbine
}

\author{
Mohd Farriz Basar \\ Faculty of Electrical \& Electronic Engineering Technology \\ Universiti Teknikal Malaysia Melaka \\ Melaka, Malaysia \\ mfarriz@utem.edu.my \\ Izadora Mustaffa \\ Faculty of Electrical \& Electronic Engineering Technology \\ Universiti Teknikal Malaysia Melaka \\ Melaka, Malaysia \\ izadora@utem.edu.my \\ Siti Nor Suhaila Mirin \\ Faculty of Electrical \& Electronic Engineering Technology \\ Universiti Teknikal Malaysia Melaka \\ Melaka, Malaysia \\ suhaila@utem.edu.my
}

\author{
Aina Musfirah Norazizi \\ Faculty of Electrical \& Electronic Engineering Technology \\ Universiti Teknikal Malaysia Melaka \\ Melaka, Malaysia \\ ainamusfirah@utem.edu.my \\ Carlos Trenado Colin \\ Leibniz Research Centre for Working Environment and \\ Human Factors at TU Dortmund University \\ Dortmund, Germany \\ trenado@ifado.de \\ Zanariah Jano \\ Institute of Technogy Management and Entrepreneurship \\ Universiti Teknikal Malaysia Melaka \\ Melaka, Malaysia \\ zanariahjano@utem.edu.my
}

\begin{abstract}
The purpose of this project was to develop an innovative, small-scale, and portable vertical axis wind turbine for power generation. The wind turbine was simple in design and economical. Wind speeds ranging from $2.0 \mathrm{~ms}^{-1}$ to $7.0 \mathrm{~ms}^{-1}$ were tested on the proposed wind turbine. The experiments revealed that the turbine required a minimum wind speed of $3.9 \mathrm{~ms}^{-1}$ to operate. According to the results, the proposed turbine achieved its maximum power output of $5.6 \mathrm{~W}$ at a rotational speed of $65 \mathrm{rpm}$ when the wind speed was $7.0 \mathrm{~m} / \mathrm{s}$. Additionally, voltage and current increased proportionately with increasing wind speed. The proposed system showed an average coefficient factor between 0.10 and 0.12 . This portable wind turbine potentially revolutionizes industry while raising public awareness about clean and renewable energy.
\end{abstract}

\section{Keyword-power generation; vertical axis; wind turbine}

\section{INTRODUCTION}

Between 2018 and 2050, global energy consumption is expected to grow by about $50 \%$. Most of this growth comes from non-Organization for Economic Cooperation and Development (non-OECD) countries, and it is concentrated in places with rapid economic growth, particularly in Asia [1]. Wind turbine power is one of the solutions to resolve these issues [2-4]. Wind power was the fastest growing energy technology in the 1990s, in terms of installed capacity and annual growth rates [4-6]. Prior to 1999, approximately $69 \%$ of all wind energy was installed in Europe, $19 \%$ in North America, and $10 \%$ in Asia and the Pacific [7]. The innovative Vertical Axis Wind Turbine (VAWT) to harness wind energy is proposed and implemented in this study.

\section{CONCEPT OF THE WIND TURBINE}

Wind turbines are a type of power generation equipment that uses the kinetic energy of the wind to generate electricity [12]. Wind turbines are typically classified into two types: Horizontal Axis Wind Turbines (HAWTs) and VAWTs [8-11]. HAWT's main rotor shaft and generator are mounted on a tower [12-15]. VAWTSs have a fixed structure and are insensitive to wind direction [16-18]. Typically, the VAWT gearbox and electrical generator are located on the system's ground [19-21]. The basic difference between VAWTs and HAWTs is their blade orientation. To construct a wind turbine model, it is necessary to understand the fundamental computation for the wind turbine's generated kinetic energy. The schematic of a VAWT is shown in Figure 1. The arrows in Figure 1 indicate the swept area for wind turbines [22]. The following equation expresses the potential power that can be harnessed from the kinetic energy of the wind [23]:

$$
P_{w}=\frac{1}{2} \rho A v^{3}
$$


where $P_{w}=$ power $(\mathrm{W}), \rho=$ density of the air $\left(\mathrm{kgm}^{-3}\right), A=$ swept area $\left(\mathrm{m}^{2}\right)$, and $v=$ velocity of wind $\left(\mathrm{ms}^{-1}\right)$.
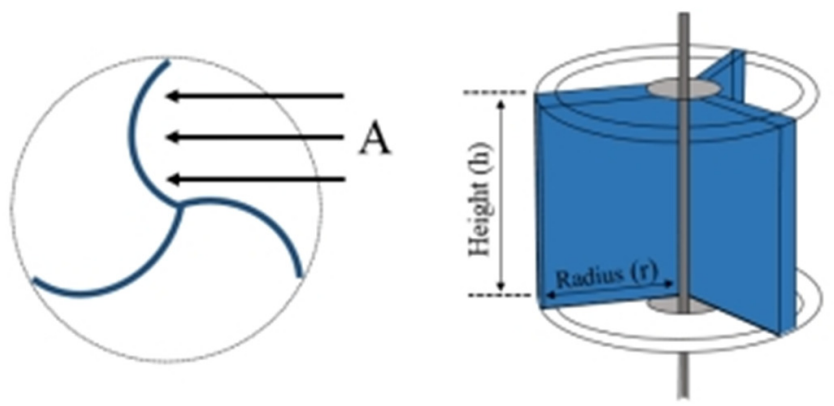

Fig. 1. Schematic vertical axis wind turbine.

The wind density of the air $(\rho)$ at sea level is $1.2256 \mathrm{kgm}^{-3}$ [10]. Theoretically, the kinetic energy generated by a wind turbine is proportional to the size of the swept area and the wind speed, as shown in (1). Large wind turbines have a large swept area. The term "swept area" refers to the cross-sectional area through which wind flows [8]. The effective swept area of a VAWT is shown in (2), as indicated by the arrows in Figure 1.

$$
A=r h
$$

According to Betz's Law, the theoretical maximum efficiency of any wind turbine design is 0.59 . A wind turbine can capture no more than $59 \%$ of the energy carried by the wind [11]. This is known as the "power coefficient," and is defined as follows:

$$
C_{P}=\frac{P_{o}}{P_{w}}
$$

where $P_{o}$ is the power generated by the wind turbine and $P_{w}$ the available power in the wind.

The power coefficient must account for all other components of a wind turbine system, such as the gearbox, bearings, and generator [11]. Large wind turbines have a power coefficient of 0.45 , but small wind turbines have a power coefficient of approximately 0.25 and can be placed in any location regardless of wind conditions [12].

\section{DESIGN AND DEVELOPMENT}

The system proposed in this study was a modification of the Savonius VAWT currently in use. It was chosen because it is capable of harnessing more wind energy than other VAWTs. The wind proposed turbine is portable, user friendly and affordable, allowing its use by the public.

\section{A. Design of a Portable VAWT}

The portable wind turbine depicted in Figure 2 was created with the Autodesk Fusion 360 software. Fusion 360 Autodesk enabled the design of various wind turbines in 2D (twodimensional) or 3D (three-dimensional) and eased material selection for each part of the model. Figure 3 shows the design of this project drawn with the Fusion 360 Autodesk. The proposed wind turbine had a simple geometrical design, consisting of three major components: the wind turbine, the generator, and a metal frame.

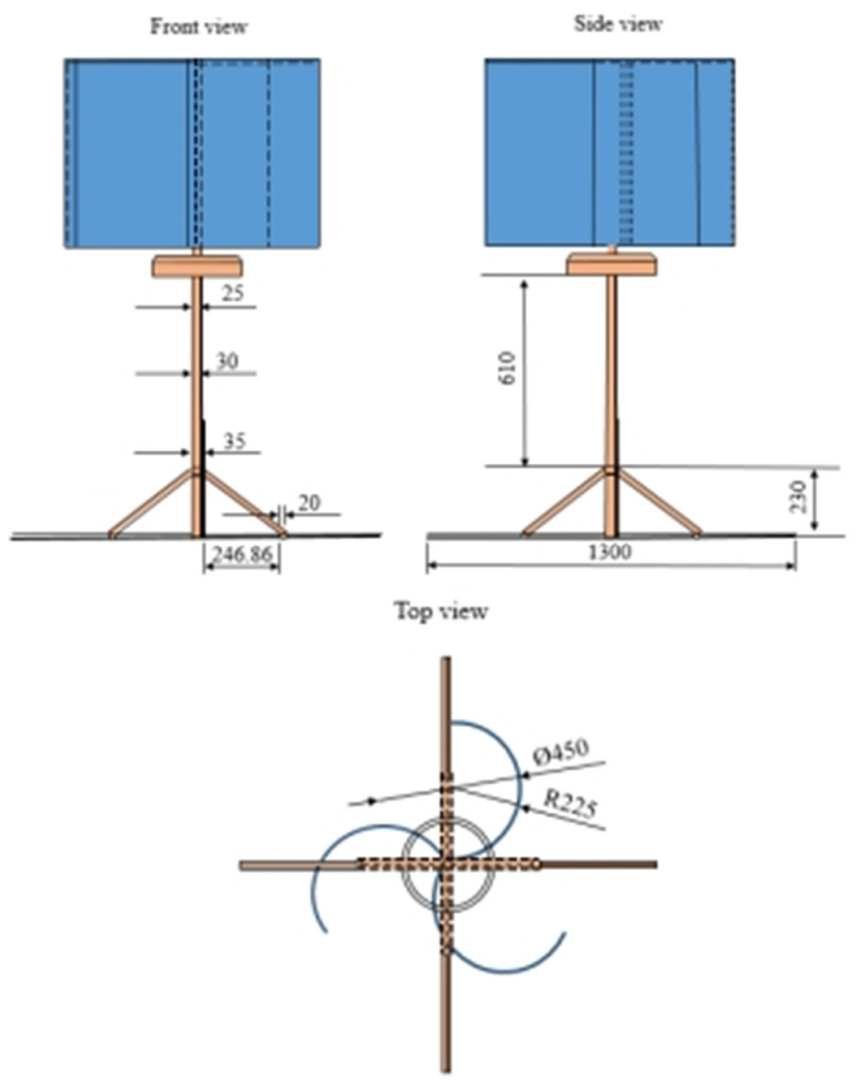

Fig. 2. VAWT design with Autodesk Fusion 360

\section{B. Development of a Low Cost VAWT}

This project was developed based on the design created by the Fusion 360 Autodesk. The system was simple to assemble and affordable in cost due to the use of basic materials available at local hardware stores. The materials used to construct the wind turbine were canvas for the blades of the turbine and round iron for the tower, pole, and blade frame. This turbine was supported by a modified stand hawking umbrella. Additionally, a DC96-01218e permanent magnet motor was installed as the generator. This motor is frequently used in washing machines to rotate the tub. The wind turbine is light, easily transportable, and easy to store or assemble. The wind turbine consisted of 3 blades with $0.60 \mathrm{~m}$ height and $0.46 \mathrm{~m}$ radius. Using (2), the effective swept area of each blade is $A=0.276 \mathrm{~m}^{2}$. This wind turbine has a total height of $1.60 \mathrm{~m}$. Figure 3 depicts a fully functional laboratory prototype.

The cost of VAWT is shown in TABLE I. The entire cost was USD $\$ 129$, and the VAWT took approximately 6 hours to complete. The cost of the materials was only US $\$ 39$, or $30.2 \%$ of the overall cost. US $\$ 90$, or $69.7 \%$ of the entire cost, was spent on labor. The most expensive component of the turbine was the round iron used for the blade frame, tower, and pole, with the total cost of US \$52 to develop. 


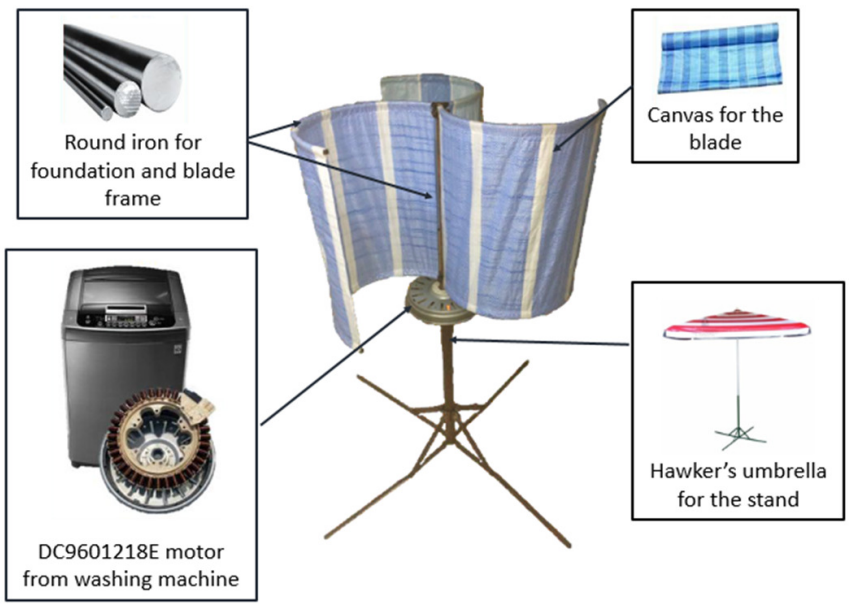

Fig. 3. A fully functional laboratory prototype.

TABLE I. VAWT COSTS

\begin{tabular}{|c|c|c|c|c|}
\hline \multirow{2}{*}{ Turbine Parts } & \multicolumn{4}{|c|}{ Costing } \\
\cline { 2 - 5 } & $\begin{array}{c}\text { Material } \\
\text { cost (USD) }\end{array}$ & $\begin{array}{c}\text { Labour } \\
\text { hours } \\
\text { (\$16/h) }\end{array}$ & $\begin{array}{c}\text { Labour } \\
\text { cost } \\
\text { (USD) }\end{array}$ & $\begin{array}{c}\text { Total } \\
\text { (USD) }\end{array}$ \\
\hline $\begin{array}{c}\text { Canvas (Qty: 3) } \\
\text { *Size : 0.46m (w) x 0.6m (h) }\end{array}$ & 4 & 1 & 16 & 20 \\
\hline $\begin{array}{c}\text { Permanent magnet } \\
\text { generator (Qty: 1) }\end{array}$ & 18 & 1 & 16 & 34 \\
\hline $\begin{array}{c}\text { Round iron for blade frame, } \\
\text { tower \& pole. (Qty 1 set) }\end{array}$ & 10 & 3 & 42 & 52 \\
\hline Turbine stand (Qty: 1) & 5 & 0.5 & 8 & 13 \\
\hline Coupling and seal. & 2 & N/A & N/A & 2 \\
\hline Assembly and balancing. & N/A & 0.5 & 8 & 8 \\
\hline Total & 39 & 6 & 90 & 129 \\
\hline \multicolumn{2}{|c|}{} & & & \\
\hline
\end{tabular}

\section{EXPERIMENTAL SETUP}

The proposed VAWT's performance was evaluated with the use of an effective experimental setup that was simple to install and closely replicated the real conditions found in low wind areas. The wind turbine was tested by applying a modest wind speed to the blade in the horizontal direction. The artificial wind speed was produced using a 26-inch stand fan with a $160 \mathrm{~W}$ motor and 3 different wind speed settings. Figure 4 shows the experimental setup in the laboratory. The stand fan was positioned at various distances from the turbine in order to generate a variety of wind speed profiles. In Figure 4, the "X" indicates the distance between the stand fan and the wind turbine. The wind speed profiles at a given distance " $\mathrm{X}$ " are shown in Table II.

The results showed that the experimental setup produced artificial wind speeds ranging from $1 \mathrm{~m} / \mathrm{s}$ to $5 \mathrm{~m} / \mathrm{s}$. A digital anemometer was used to determine the wind speed. Meanwhile, a digital Onosokki HT-4200 tachometer was utilized to determine the rotational speed of the wind turbine blade. The tachometer was able to detect speed without touching the moving item due to the addition of a reflector. The following are some aspects to consider when performing such experiments:
- Ensure there are no additional wind sources inside the laboratory.

- Experimental data are to be measured and recorded after the turbine has been spinning for $30 \mathrm{~s}$.

- Ensure the canvas used as a turbine blade is in a good condition before the experiment.

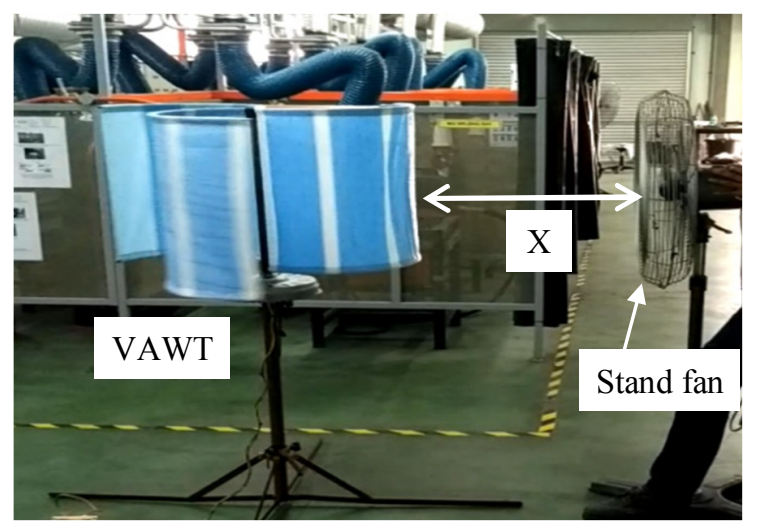

Fig. 4. Experimental setup.

TABLE II. WIND SPEED PROFILES

\begin{tabular}{|c|c|c|}
\hline \multirow{2}{*}{ Fan speed } & \multicolumn{2}{|c|}{$\begin{array}{c}\text { Distance between the stand fan } \\
\text { and the wind turbine (X) }\end{array}$} \\
\cline { 2 - 3 } & $\mathbf{1 ~ m}$ & $\mathbf{2 ~} \mathbf{~ m}$ \\
\hline Low (Knob 1) & $2.8 \mathrm{~ms}^{-1}$ & $2.0 \mathrm{~ms}^{-1}$ \\
\hline Medium (Knob 2) & $4.8 \mathrm{~ms}^{-1}$ & $3.9 \mathrm{~ms}^{-1}$ \\
\hline High (Knob 3) & $7.0 \mathrm{~ms}^{-1}$ & $5.1 \mathrm{~ms}^{-1}$ \\
\hline
\end{tabular}

\section{PERFORMANCE ANALYSIS}

Figures 5 and 6 and Tables III-V depict the proposed wind turbine's theoretical and measured performance curves. The results were shown for various wind speeds, with an emphasis on those less than $5 \mathrm{~m} / \mathrm{s}$.

\section{A. Minimum Wind Speed}

The section discusses the minimal wind speed required to rotate a wind turbine's blade. Using the experiment setup discussed above, the speed was increased incrementally while simultaneously determining whether the blade rotated or not. Once the blade rotated, the generator's output voltage was monitored. When the wind speed was $3.9 \mathrm{~ms}^{-1}$, the blades of VAWT began rotating at $35 \mathrm{rpm}$ and concurrently created a voltage of 9.6V (Figure 5, Table III). If the wind speed was less than $2.8 \mathrm{~ms}^{-1}$, the turbine did not run, and no output was generated. In order to move the turbine blade from its stationary position, wind with greater force and kinetic energy were required to push the turbine's mass and overcome the motor's torque. Additionally, the experimental results indicated that the proposed system generated $15.1 \mathrm{~V}$ at $65 \mathrm{rpm}$ with a wind speed of $7.0 \mathrm{~ms}^{-1}$. When the wind speed increased, the blade speed and the voltage output increased continually. The results demonstrated that the proposed VAWT was able to produce significant power at low wind speeds. 
TABLE III. BLADE SPEED FOR VARIOUS WIND SPEEDS

\begin{tabular}{|c|c|c|}
\hline Wind speed & Blade speed & Voltage $\left(\boldsymbol{V}_{\boldsymbol{o c}}\right)$ \\
\hline $2.0 \mathrm{~ms}^{-1}$ & $0 \mathrm{rpm}$ & $0.0 \mathrm{~V}$ \\
\hline $2.8 \mathrm{~ms}^{-1}$ & $0 \mathrm{rpm}$ & $0.0 \mathrm{~V}$ \\
\hline $3.9 \mathrm{~ms}^{-1}$ & $35 \mathrm{rpm}$ & $9.6 \mathrm{~V}$ \\
\hline $4.8 \mathrm{~ms}^{-1}$ & $43 \mathrm{rpm}$ & $11.1 \mathrm{~V}$ \\
\hline $5.1 \mathrm{~ms}^{-1}$ & $51 \mathrm{rpm}$ & $12.5 \mathrm{~V}$ \\
\hline $7.0 \mathrm{~ms}^{-1}$ & $65 \mathrm{rpm}$ & $15.1 \mathrm{~V}$ \\
\hline
\end{tabular}

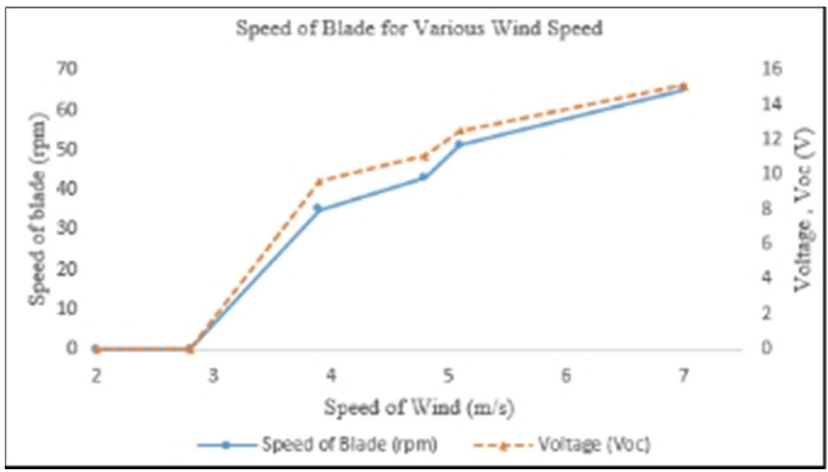

Fig. 5. Blade speed and generated voltage.

\section{B. Power Output and Efficiency}

This section examines the power generated by the wind turbine, the accessible power in the wind, and the system's efficiency. The voltage and current generated by the system should be determined. Tables IV and V and Figure 6 demonstrate the proposed wind turbine's overall performance.

TABLE IV. POWER OUTPUT

\begin{tabular}{|c|c|c|c|}
\hline Wind speed & Voltage $\left(\boldsymbol{V}_{\boldsymbol{o c}}\right)$ & Current $\left(\boldsymbol{I}_{\boldsymbol{s c}}\right)$ & Power output $\left(\boldsymbol{P}_{\boldsymbol{o}}\right)$ \\
\hline $2.8 \mathrm{~ms}^{-1}$ & $0.0 \mathrm{~V}$ & $0.0 \mathrm{~A}$ & $0.0 \mathrm{~W}$ \\
\hline $3.9 \mathrm{~ms}^{-1}$ & $9.6 \mathrm{~V}$ & $0.1 \mathrm{~A}$ & $1.0 \mathrm{~W}$ \\
\hline $4.8 \mathrm{~ms}^{-1}$ & $11.1 \mathrm{~V}$ & $0.16 \mathrm{~A}$ & $1.8 \mathrm{~W}$ \\
\hline $5.1 \mathrm{~ms}^{-1}$ & $12.5 \mathrm{~V}$ & $0.21 \mathrm{~A}$ & $2.6 \mathrm{~W}$ \\
\hline $7.0 \mathrm{~ms}^{-1}$ & $15.1 \mathrm{~V}$ & $0.37 \mathrm{~A}$ & $5.6 \mathrm{~W}$ \\
\hline
\end{tabular}

TABLE V. EFFICIENCY OF THE PROPOSED VAWT

\begin{tabular}{|c|c|c|c|}
\hline Wind speed & $\begin{array}{c}\text { Power output } \\
\left(\boldsymbol{P}_{\boldsymbol{o}}\right)\end{array}$ & $\begin{array}{c}\text { Potential power } \\
\left(\boldsymbol{P}_{\boldsymbol{w}}\right)\end{array}$ & $\begin{array}{c}\text { Coefficient } \\
\text { factor }\left(\boldsymbol{C}_{\boldsymbol{p}}\right)\end{array}$ \\
\hline $2.8 \mathrm{~ms}^{-1}$ & $0.0 \mathrm{~W}$ & $3.9 \mathrm{~W}$ & 0.00 \\
\hline $3.9 \mathrm{~ms}^{-1}$ & $1.0 \mathrm{~W}$ & $9.7 \mathrm{~W}$ & 0.11 \\
\hline $4.8 \mathrm{~ms}^{-1}$ & $1.8 \mathrm{~W}$ & $18.1 \mathrm{~W}$ & 0.10 \\
\hline $5.1 \mathrm{~ms}^{-1}$ & $2.6 \mathrm{~W}$ & $21.7 \mathrm{~W}$ & 0.12 \\
\hline $7.0 \mathrm{~ms}^{-1}$ & $5.6 \mathrm{~W}$ & $56.1 \mathrm{~W}$ & 0.10 \\
\hline
\end{tabular}

According to Table IV, when the speed was less than $2.8 \mathrm{~ms}^{-1}$, no power was generated from the wind turbine, because it could not function when the blades were idle. Additionally, the power generated increased continually as the wind speed increased. The highest output power was $5.6 \mathrm{~W}$ when the wind speed was $7.0 \mathrm{~ms}^{-1}$. The voltage generated at that moment was $15.1 \mathrm{~V}$ and the current was $0.37 \mathrm{~A}$. When the speed turbine was set to $3.9 \mathrm{~ms}^{-1}$, the power output and the generated current were $1.0 \mathrm{~W}$ and $0.1 \mathrm{~A}$ respectively. After measuring the proposed wind turbine's power output, the efficiency was determined. Equation (1) was used to determine the wind's potential power. Thus, using an effective swept area $(A)$ of
$0.276 \mathrm{~m}^{2}$ and an air density $(\rho)$ of $1.22 \mathrm{kgm}^{-3}$, the proposed wind turbine's efficiency was calculated, and the results are shown in Table V.

According to Table $\mathrm{V}$ and Figure 6, the coefficient factor $\left(C_{p}\right)$ ranged between 0.10 and 0.12 . This is consistent with the discussion in Section II, where the maximum $C_{p}$ for a wind turbine was determined as 0.59 . The experimental results demonstrated that the proposed system operated at an acceptable coefficient factor. As wind speed increased, the value of the power output and the potential power increased proportionately. However, the $C_{p}$ value remained between 0.10 and 0.12 . The greatest potential power was generated when the wind speed was $8.3 \mathrm{~ms}^{-1}$.

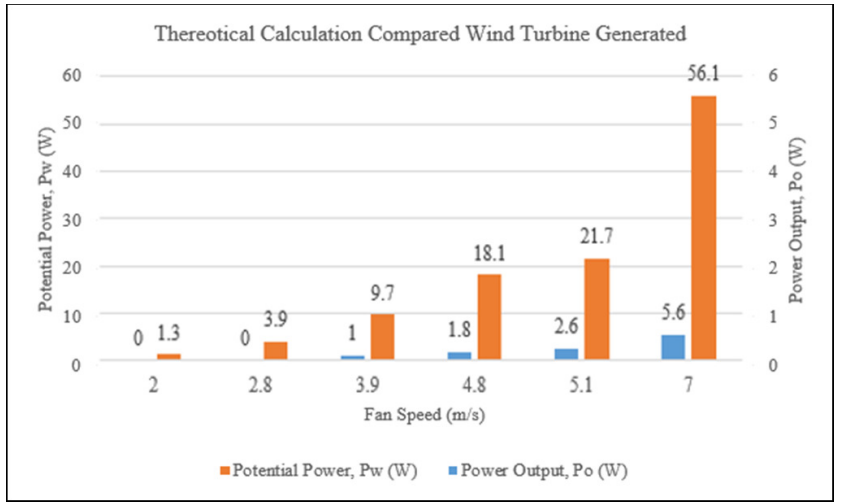

Fig. 6. Potential power and power output.

In [10], the authors created a Savonius VAWT. They modified the typical Savonius wind turbine model by adding single and multiple layer blades. Wind rates of $6.46,6.99$, and $7.27 \mathrm{~m} / \mathrm{s}$ were used to test the system. The experimental results indicated that the redesigned wind turbine exhibits $C p$ values ranging from 0.02 to 0.12 . Additionally, the actual power obtained was between $2.2 \mathrm{~W}$ and $4.2 \mathrm{~W}$. The proposed turbine in the current study performs similarly to the one in [10]. Both turbines perform similarly in terms of $C_{p}$ and output power when wind speeds are identical. This demonstrates that the proposed wind turbine's performance is acceptable and that it can contribute to the field of wind energy generation.

\section{CONCLUSION}

Overall, the designed wind turbine works satisfactorily. Despite its simplicity and low cost, the system is capable of producing a significant output power of up to $5.6 \mathrm{~W}$ with an acceptable coefficient factor of 0.10 to 0.12 . Additionally, laboratory testing demonstrates that these wind turbines can generate power even when exposed to low-speed winds, less than $7.0 \mathrm{~ms}^{-1}$. This research also demonstrates that the proposed wind turbine will operate when a minimal wind speed $3.9 \mathrm{~ms}^{-1}$ is available to move the turbine blades. The higher the wind speed, the higher the voltage, current, and the created power output. Further research is needed to determine the impact of blade number and size on system performance. Electric generators can also be diversified to produce more power. 


\section{ACKNOWLEDGEMENT}

The authors would like to express their appreciation to the Universiti Teknikal Malaysia Melaka (UTeM) for supplying the laboratory space and technical help. Additionally, the authors would like to express their gratitude to Mr. Mohammad Faisal Zulfaqqar Bin Hasbullah for his technical assistance.

\section{REFERENCES}

[1] "EIA projects nearly $50 \%$ increase in world energy usage by 2050 , led by growth in Asia," US Energy Information Administration - Today in Energy, Sep. 24, 2019. https://www.eia.gov/todayinenergy/ detail.php?id=41433 (accessed Oct. 26, 2021).

[2] I. Malael and V. Dragan, "Numerical and Experimental Efficiency Evaluation of a Counter-Rotating Vertical Axis Wind Turbine," Engineering, Technology \& Applied Science Research, vol. 8, no. 4, pp. 3282-3286, Aug. 2018, https://doi.org/10.48084/etasr.2231.

[3] M. B. Farriz, A. N. Azmi, N. A. M. Said, A. Ahmad, and K. A. Baharin, "A study on the wind as a potential of renewable energy sources in Malaysia," in ECTI-CON2010: The 2010 ECTI International Confernce on Electrical Engineering/Electronics, Computer, Telecommunications and Information Technology, Chiang Mai, Thailand, May 2010, pp. 651-655.

[4] P. A. C. Rocha et al., "The effects of blade pitch angle on the performance of small-scale wind turbine in urban environments," Energy, vol. 148, pp. 169-178, Apr. 2018, https://doi.org/10.1016/ j.energy.2018.01.096.

[5] W. Tian, Z. Mao, B. Zhang, and Y. Li, "Shape optimization of a Savonius wind rotor with different convex and concave sides," Renewable Energy, vol. 117, pp. 287-299, Mar. 2018, https://doi.org/ 10.1016/j.renene.2017.10.067.

[6] R. Gupta, A. Biswas, and K. K. Sharma, "Comparative study of a threebucket Savonius rotor with a combined three-bucket Savonius-threebladed Darrieus rotor," Renewable Energy, vol. 33, no. 9, pp. 19741981, Sep. 2008, https://doi.org/10.1016/j.renene.2007.12.008.

[7] J. B. V. Subrahmanyam, P. Alluvada, Bandana, K. Bhanupriya, and C. Shashidhar, "Renewable Energy Systems: Development and Perspectives of a Hybrid Solar-Wind System," Engineering, Technology \& Applied Science Research, vol. 2, no. 1, pp. 177-181, Feb. 2012, https://doi.org/10.48084/etasr.104.

[8] K. Sahim, D. Santoso, and D. Puspitasari, "Investigations on the Effect of Radius Rotor in Combined Darrieus-Savonius Wind Turbine," International Journal of Rotating Machinery, vol. 2018, Mar. 2018, Art. no. e3568542, https://doi.org/10.1155/2018/3568542.

[9] Y. Kyozuka, "An Experimental Study on the Darrieus-Savonius Turbine for the Tidal Current Power Generation," Journal of Fluid Science and Technology, vol. 3, no. 3, pp. 439-449, 2008, https://doi.org/10.1299/ jfst.3.439.

[10] Y. Kurniawan, D. D. D. P. Tjahjana, and B. Santoso, "Experimental Study of Savonius Wind Turbine Performance with Blade Layer Addition," Journal of Advanced Research in Fluid Mechanics and Thermal Sciences, vol. 69, no. 1, pp. 23-33, Dec. 2020.

[11] I. Paraschivoiu, O. Trifu, and F. Saeed, "H-Darrieus Wind Turbine with Blade Pitch Control," International Journal of Rotating Machinery, vol. 2009, May 2009, Art. no. e505343, https://doi.org/10.1155/2009/ 505343.

[12] H. Dumitrescu, A. Dumitrache, F. Frunzulica, A. Pal, and V. Turbatu, "TORNADO concept and realisation of a rotor for small VAWTs," INCAS BULLETIN, vol. 5, no. 3, pp. 69-75, Sep. 2013, https://doi.org/10.13111/2066-8201.2013.5.3.8.

[13] M. J. Werle and W. M. Presz, "Ducted Wind/Water Turbines and Propellers Revisited," Journal of Propulsion and Power, vol. 24, no. 5, pp. 1146-1150, Sep. 2008, https://doi.org/10.2514/1.37134.

[14] S. Ivanell, J. N. Sørensen, and D. Henningson, "Numerical Computations of Wind Turbine Wakes," in Wind Energy, Berlin, Heidelberg, 2007, pp. 259-263, https://doi.org/10.1007/978-3-54033866-6 48 .
[15] D. Hartwanger and A. Horvat, "3D modelling of a wind turbine using CFD," presented at the NAFEMS UK Conference 2008, Cheltenham, UK, Jun. 2008.

[16] M. Raciti Castelli, A. Englaro, and E. Benini, "The Darrieus wind turbine: Proposal for a new performance prediction model based on CFD," Energy, vol. 36, no. 8, pp. 4919-4934, Aug. 2011, https://doi.org/ 10.1016/j.energy.2011.05.036.

[17] B. Memon, M. H. Baloch, A. H. Memon, S. H. Qazi, R. Haider, and D. Ishak, "Assessment of Wind Power Potential Based on Raleigh Distribution Model: An Experimental Investigation for Coastal Zone," Engineering, Technology \& Applied Science Research, vol. 9, no. 1, pp. 3721-3725, Feb. 2019, https://doi.org/10.48084/etasr.2381.

[18] W. A. Timmer and R. P. J. O. M. van Rooij, "Summary of the Delft University Wind Turbine Dedicated Airfoils," Journal of Solar Energy Engineering, vol. 125 , no. 4, pp. 488-496, Nov. 2003, https://doi.org/ 10.1115/1.1626129.

[19] I. Mălăel, V. Drăgan, and G. Vizitiu, "The Vertical Axis Wind Turbine Efficiency Evaluation by Using the CFD Methods," Applied Mechanics and Materials, vol. 772, pp. 90-95, 2015, https://doi.org/10.4028/ www.scientific.net/AMM.772.90.

[20] H. Dumitrescu, V. Cardoş, and I. Mălăel, "The Physics of Starting Process for Vertical Axis Wind Turbines," in CFD for Wind and Tidal Offshore Turbines, E. Ferrer and A. Montlaur, Eds. Cham, Switzerland: Springer, 2015, pp. 69-81, https://doi.org/10.1007/978-3-319-162027 7.

[21] G. Naccache and M. Paraschivoiu, "Parametric study of the dual vertical axis wind turbine using CFD," Journal of Wind Engineering and Industrial Aerodynamics, vol. 172, pp. 244-255, Jan. 2018, https://doi.org/10.1016/j.jweia.2017.11.007.

[22] M. Dranca, M. Chirca, V. Zaharia, A. Zaharia, and S. Breban, "Permanent magnet generator for counter-rotating vertical axis microwind turbine," in 2017 52nd International Universities Power Engineering Conference (UPEC), Heraklion, Greece, Aug. 2017, https://doi.org/10.1109/UPEC.2017.8231959.

[23] R. Howell, N. Qin, J. Edwards, and N. Durrani, "Wind tunnel and numerical study of a small vertical axis wind turbine," Renewable Energy, vol. 35, no. 2, pp. 412-422, Feb. 2010, https://doi.org/ 10.1016/j.renene.2009.07.025. 